\title{
Tracing devastating fires in Portugal to a snow archive in the Swiss Alps: a case study
}

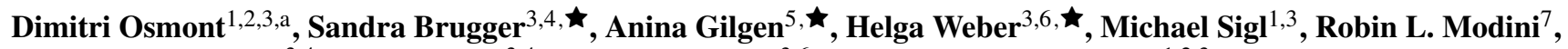 \\ Christoph Schwörer $^{3,4}$, Willy Tinner ${ }^{3,4}$, Stefan Wunderle ${ }^{3,6}$, and Margit Schwikowski ${ }^{1,2,3}$ \\ ${ }^{1}$ Laboratory of Environmental Chemistry, Paul Scherrer Institut, 5232 Villigen, Switzerland \\ ${ }^{2}$ Department of Chemistry and Biochemistry, University of Bern, 3012 Bern, Switzerland \\ ${ }^{3}$ Oeschger Centre for Climate Change Research, University of Bern, 3012 Bern, Switzerland \\ ${ }^{4}$ Institute of Plant Sciences, University of Bern, 3012 Bern, Switzerland \\ ${ }^{5}$ Institute for Atmospheric and Climate Science, ETH Zürich, 8092 Zürich, Switzerland \\ ${ }^{6}$ Institute of Geography, University of Bern, 3012 Bern, Switzerland \\ ${ }^{7}$ Laboratory of Atmospheric Chemistry, Paul Scherrer Institut, 5232 Villigen, Switzerland \\ a current address: Institut des Géosciences de l'Environnement, Université Grenoble-Alpes, \\ 38400 Saint Martin d'Hères, France \\ ฟhese authors contributed equally to this work.
}

Correspondence: Margit Schwikowski (margit.schwikowski@psi.ch)

Received: 17 February 2020 - Discussion started: 5 March 2020

Revised: 23 July 2020 - Accepted: 11 August 2020 - Published: 5 November 2020

\begin{abstract}
Recent large wildfires, such as those in Portugal in 2017, have devastating impacts on societies, economy, ecosystems and environments. However, wildfires are a natural phenomenon, which has been exacerbated by land use during the past millennia. Ice cores are one of the archives preserving information on fire occurrences over these timescales. A difficulty is that emission sensitivity of ice cores is often unknown, which constitutes a source of uncertainty in the interpretation of such archives. Information from specific and well-documented case studies is therefore useful to better understand the spatial representation of icecore burning records. The wildfires near Pedrógão Grande in central Portugal in 2017 provided a test bed to link a fire event to its footprint left in a high-alpine snowpack considered a surrogate for high-alpine ice-core sites. Here, we (1) analysed black carbon (BC) and microscopic charcoal particles deposited in the snowpack close to the high-alpine research station Jungfraujoch in the Swiss Alps; (2) calculated backward trajectories based on ERA-Interim reanalysis data and simulated the transport of these carbonaceous particles using a global aerosol-climate model; and (3) analysed the fire spread, its spatial and temporal extent, and its intensity with remote-sensing (e.g. MODIS) Active Fire and
\end{abstract}

Burned Area products. According to modelled emissions of the FINN v1.6 database, the fire emitted a total amount of $203.5 \mathrm{t} \mathrm{BC}$ from a total burned area of $501 \mathrm{~km}^{2}$ as observed on the basis of satellite fire products. Backward trajectories unambiguously linked a peak of atmospheric-equivalent BC observed at the Jungfraujoch research station on 22 June with elevated levels until 25 June - with the highly intensive fires in Portugal. The atmospheric signal is in correspondence with an outstanding peak in microscopic charcoal observed in the snow layer, depositing nearly as many charcoal particles as during an average year in other ice archives. In contrast to charcoal, the amount of atmospheric BC deposited during the fire episode was minor due to a lack of precipitation. Simulations with a global aerosol-climate model suggest that the observed microscopic charcoal particles originated from the fires in Portugal and that their contribution to the BC signal in snow was negligible. Our study revealed that microscopic charcoal can be transported over long distances $(1500 \mathrm{~km})$ and that snow and ice archives are much more sensitive to distant events than sedimentary archives, for which the signal is dominated by local fires. The findings are important for future ice-core studies as they document that, for $\mathrm{BC}$ as a fire tracer, the signal preservation 
depends on precipitation. Single events, like this example, might not be preserved due to unfavourable meteorological conditions.

\section{Introduction}

Fires are an important component of terrestrial ecosystems as they substantially control vegetation cover and contribute to the global carbon budget (e.g. Bond et al., 2005; Hantson et al., 2015). Global $\mathrm{CO}_{2}$ emissions from fires, including landscape and biomass (i.e. biomass combustion from domestic and industrial uses), represent around $50 \%$ of those produced by fossil fuel burning (Bowmann et al., 2009). Fires exert an influence on the climate system as they emit greenhouse gases and aerosols (Andreae and Merlet, 2001) and change surface albedo (Randerson et al., 2006) as well as on vegetation and soil carbon (Page et al., 2002). In the last 2 decades, the occurrence of devastating wildfires has increased in many regions of the world, leading to substantial socioeconomic and environmental consequences (Moritz et al., 2014). In the context of global warming, fire risk (Pechony et al., 2010), frequency (Keywood et al., 2013) and season severity (Flannigan et al., 2013) are potentially increasing with significant feedbacks on terrestrial and atmospheric systems (Bowman et al., 2011). To understand these future impacts, palaeofire reconstructions provide an important tool for assessing long-term changes in past fire activity and can help to disentangle the influence of climate and humans on biomass burning. Most of the currently available sedimentary records have large chronological uncertainties in the youngest part of the records (Marlon et al., 2016) and reflect small local to regional catchments (Adolf et al., 2018). To address global fire activity trends, ice cores from polar (see e.g. Arienzo et al., 2017; Fischer et al., 2015; Keegan et al., 2014; Legrand et al., 1992, 2016; Legrand and De Angelis, 1996, Whitlow et al., 1994; Zennaro et al., 2014) and high-altitude glaciers (see e.g. Brugger et al., 2018a, 2019a; Eichler et al., 2011; Osmont et al., 2018, 2019; Yalcin et al., 2006) have a high potential since they record fire activity from regional to continental scales and usually provide well-constrained chronologies (see e.g. Herren et al., 2013; Konrad et al., 2013; Uglietti et al., 2016).

Fires emit a wide range of chemical compounds and particles to the atmosphere, such as black carbon (BC) and charcoal. If transported over long distances, these particles can be deposited with precipitation or by gravitational settling on the snowpack, where they will be archived, and can be subsequently retrieved by ice-core drilling. However, icecore catchment areas are not often precisely known due to a lack of information about emission, transport and deposition processes. Case studies are essential to understand these processes, including fire extent, fuel load, plume transport, biomass burning tracer deposition and preservation in the snowpack (e.g. Kaspari et al., 2015). Modelling of fire tracers (e.g. BC or charcoal) from the fire source to the deposition site provides a direct link and quantification of the archived biomass burning tracers. Detailed information to quantify the amount, frequency and intensity of biomass burning emissions relies mainly on satellite observations (e.g. occurrence of active fires; fire radiative power, i.e. intensity, FRP; burned area; and vegetation cover). A limiting factor is the availability of long-term satellite products with sufficient temporal and spatial resolution. Recently, an Active Fire product was developed for Europe reaching back until 1985 (see Weber and Wunderle, 2019). Therefore, a direct linkage between specific fire events and ice-core observations is very challenging, especially for biomass burning events that occurred some decades or centuries ago. Thus, the fire footprint of ice-core sites and the preservation of single biomass burning events in these archives remain largely unknown. Pioneer case studies have shown that elevated concentrations of ammonium, potassium and formate in Greenland's atmosphere and snow could be directly linked to forest fires in Canada (Dibb et al., 1996). More recent case studies confirmed that $\mathrm{BC}$ emissions from fires can be preserved in snow and ice archives at subcontinental scales. For instance, BC peaks in Greenland snow pits were associated with specific biomass burning events in Canada with the help of remote sensing and modelling tools (Thomas et al., 2017). BC emissions from the oil well fires in Kuwait in 1991 during the Gulf War were detected unambiguously in an ice core from Muztagh Ata, northern Tibet (Zhou et al., 2018). However, for Europe, characterized by highly fragmented landscapes and smaller mean burned area compared to other continents (Mouillot and Field, 2005), specific case studies are missing.

Here, we focus on an outstanding wildfire event starting on 17 June 2017 in Portugal. Portugal was affected by a severe heat wave with temperatures above $40^{\circ} \mathrm{C}$ in June 2017 , and during a dry thunderstorm, lightning ignited the forests dominated by non-native Eucalyptus plantations near Pedrógão Grande in central Portugal (Fig. 1). The highly flammable vegetation resulted in a rapid and uncontrolled spread of the fire with devastating impacts, leading to the worst death toll Portugal has ever experienced for a fire. A total of 64 people lost their life, and 254 were injured (Gómez-González et al., 2018 ) before the fires were finally extinguished on 24 June. A large plume of smoke was emitted and transported to the north-east from the burning site. On 21 June, the automatic lidar operated by MeteoSwiss (Federal Office of Meteorology and Climatology, Switzerland) in Payerne, Switzerland, detected a layer of smoke between 3000 and $5000 \mathrm{~m}$ a.s.l. corresponding to the arrival of the plume. The signal intensified on 22 June, and its Portuguese origin was confirmed by atmospheric backward trajectory analysis (MeteoSwiss, 2017). The smoke layer became visible in the morning hours of 22 June on the Jungfraujoch (JFJ) research station webcam, located at $3580 \mathrm{~m}$ a.s.l. in the Bernese Alps. At the same time, a peak in atmospheric-equivalent black carbon $(\mathrm{eBC})$ was de- 

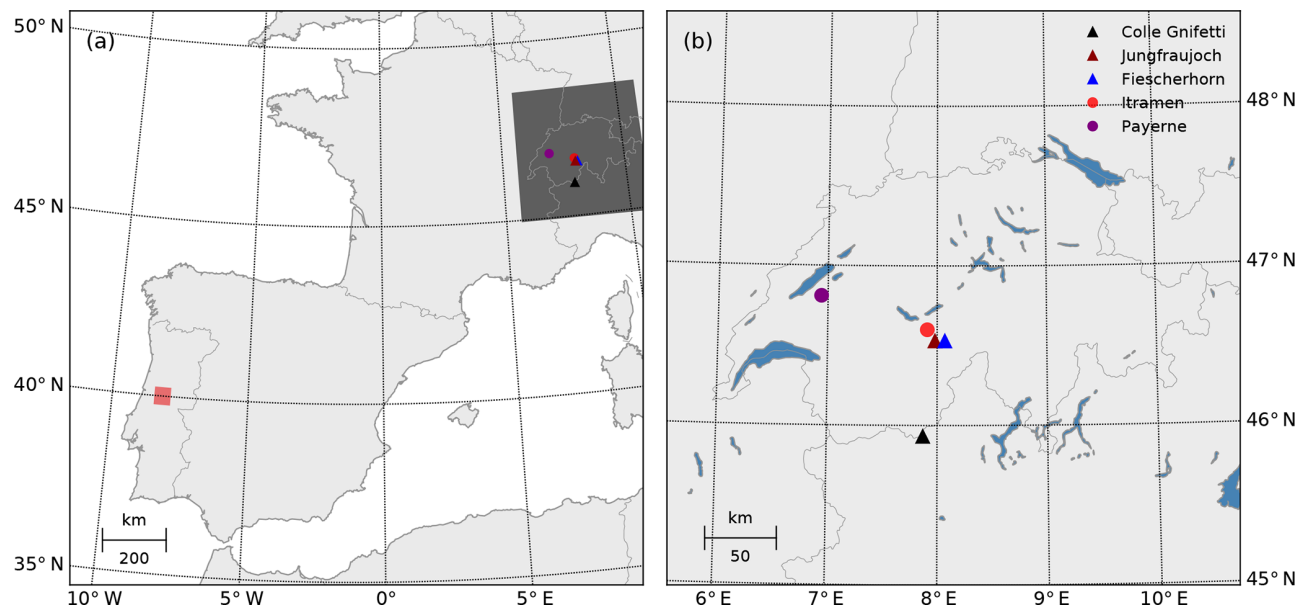

Figure 1. Source and deposition sites. (a) Map of south-western Europe with the area of Pedrógão Grande, in central Portugal, where the fires burned (red box), and the area of the zoom in the right panel (grey box). (b) Map of Switzerland with the sites of interest mentioned in the study. Triangles indicate high-altitude ice-core and snow study sites; circles stand for weather stations.

tected by the Multi-Angle Absorption Photometer (MAAP; optical method for BC quantification; Petzold and Schönlinner, 2004) installed at the research station (Fig. 2a). The term $\mathrm{eBC}$ is used for black carbon data derived from optical absorption methods together with a suitable mass absorption cross section (MAC) for the conversion of light absorption coefficient into mass concentration (Petzold et al., 2013). Elevated eBC values lasted until 25 June, when the first snowfall after the event occurred.

The exceptional conditions of this Portuguese fire event producing a plume that was recorded unambiguously at the high-alpine research station JFJ in Switzerland, located close to perennial snow archives, provided an ideal situation to analyse in detail the processes related to emission, transport and deposition of fire tracers in a high-mountain snowpack.

\section{Methods}

\subsection{Study site and meteorological conditions}

The high-altitude research station Jungfraujoch $\left(46^{\circ} 32^{\prime} \mathrm{N}\right.$, $7^{\circ} 59^{\prime} \mathrm{E}$; Fig. 1) is located on the pass between the summits of Jungfrau and Mönch in the Bernese Alps. Built at an altitude of $3580 \mathrm{~m}$ a.s.l., the surrounding high-alpine environment is characterized by glaciers and cliffs. The north side, facing the Swiss Plateau, consists of a steep ice fall, while the relatively flat south slopes host the large Jungfraufirn glacier feeding the Aletsch glacier. The JFJ site lies only partially within the free troposphere, being frequently influenced by uplifted air from the planetary boundary layer (e.g. Baltensperger et al., 1997; Bukowiecki et al., 2016). Aerosol monitoring at JFJ provides continuous long-term atmospheric records of many parameters including $\mathrm{eBC}$ concentration. In addition, a weather station provides meteorologi- cal data, but precipitation is not monitored at JFJ due to the difficulty of obtaining accurate data as most precipitation occurs in the form of snow in frequent association with strong winds. The closest precipitation data available are from the automatic weather station Itramen (2162 $\mathrm{m}$ a.s.l.), operated by the Institute for Snow and Avalanche Research (WSLSLF) and located $9 \mathrm{~km}$ to the north-west of JFJ. Following the Portugal fires, precipitation (rainfall) was recorded at Itramen on 25-29 June, bringing 32, 42.8, 2.0, 49.6 and $35.2 \mathrm{~mm}$ of water, respectively (data from SLF ( 9 2019). We used the JFJ webcam to determine whether snowfall occurred at the same time at JFJ, which was the case except for 27 June.

\subsection{Snow pit and sampling}

A snow pit was collected on 30 June 2017, around $20 \mathrm{~m}$ off the prepared trail between JFJ and Mönchsjochhütte and $400 \mathrm{~m}$ east from the Jungfraujoch tunnel exit onto the glacier, at an altitude of $3460 \mathrm{~m}$ a.s.l. A massive ice layer prevented us from digging deeper than $1.10 \mathrm{~m}$. Density was measured on the spot for each layer by weighing a stainless steel cylinder of known volume filled with snow. Following the stratigraphic study, 20 samples were collected at about $5 \mathrm{~cm}$ resolution by pushing pre-cleaned $50 \mathrm{~mL}$ polypropylene vials vertically in the snow wall. Ice layers were sampled specifically (if thick enough) to check the potential impact of melting on the chemical composition of the snowpack. A total of 20 replicate samples were retrieved at the same resolution to test the reproducibility of the experiment. In addition, six pre-cleaned $1 \mathrm{~L}$ PETG jars were filled with 0.2 to $0.5 \mathrm{~kg}$ snow for microscopic charcoal analysis at $10 \mathrm{~cm}$ resolution between 20 and $80 \mathrm{~cm}$ depth. 

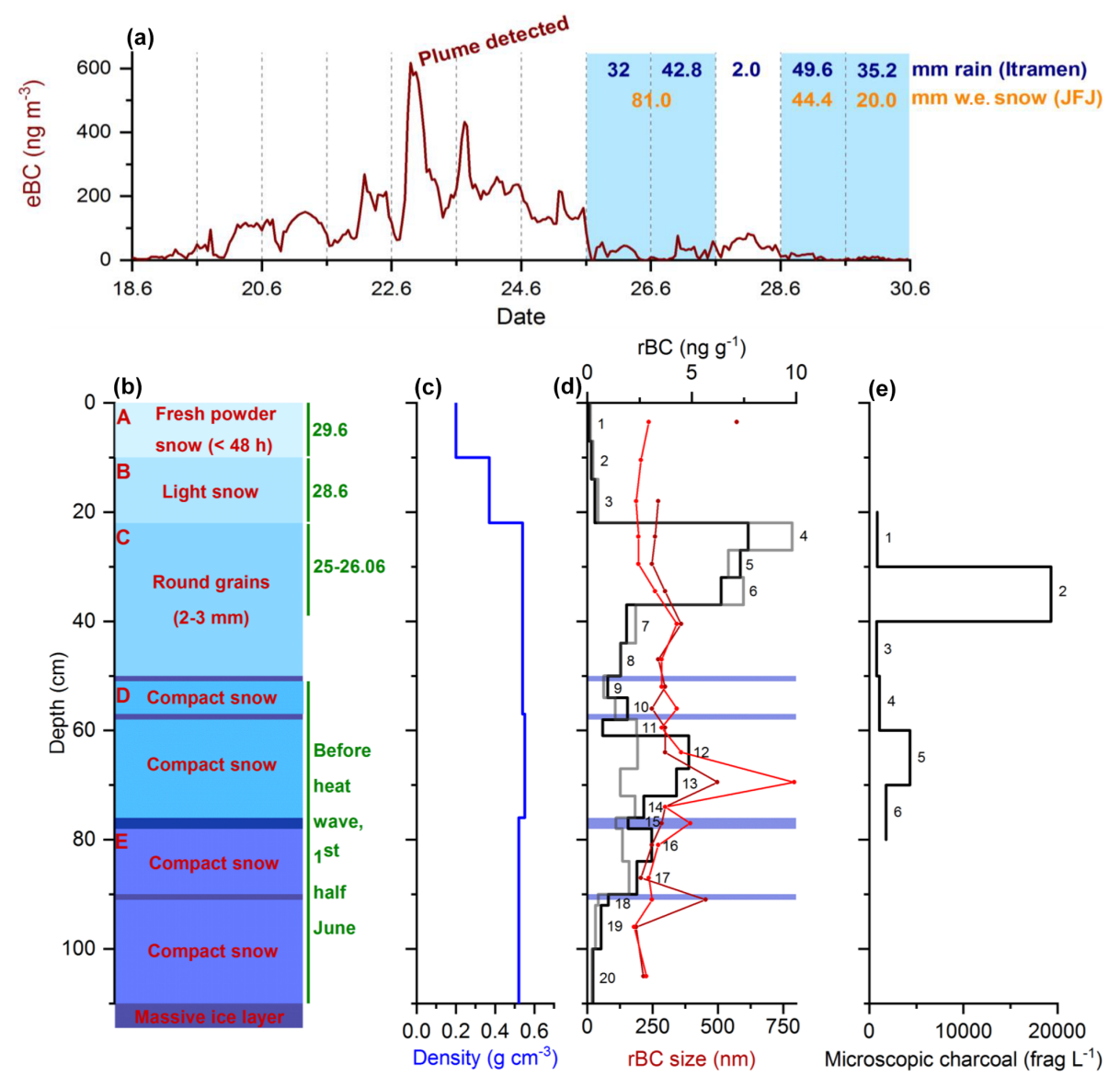

Figure 2. (a) Atmospheric-equivalent black carbon (eBC) concentrations at Jungfraujoch showing the peak on 22 June when the plume of smoke reached the site. A mass absorption coefficient of $10 \mathrm{~m}^{2} \mathrm{~g}^{-1}$ was assumed. Blue bars indicate days with significant snowfall at JFJ, with a comparison between the daily precipitation amount measured at Itramen (values in blue in millimetres; data from SLF (c) 2019) and the daily snowfall height inferred from the snow pit at JFJ, corrected for density (values in orange in millimetres of water equivalent, w.e.). (b) Snow pit stratigraphy with ice lenses in dark blue. (c) Density profile of the snow pit. (d) The rBC concentration profile (top scale) with the two series of replicates (black and grey) and associated sample number. Mode of the rBC mass size distribution (bottom scale) with the two series of replicates (dark red and red). Blue bars are ice lenses. (e) Microscopic charcoal concentration record.

\subsection{Analytical methods}

Samples were stored in a frozen state and were melted just before analysis of refractory $\mathrm{BC}(\mathrm{rBC})$ and major ions at the Paul Scherrer Institute. The abbreviation $\mathrm{rBC}$ stands for black carbon measured by incandescence methods (Petzold et al., 2013), and analysis followed the method described by Wendl et al. (2014): after sample melting at room temperature and a $25 \mathrm{~min}$ sonication in an ultrasonic bath, rBC was quantified using a Single Particle Soot Photometer (SP2, Droplet Measurement Technologies, USA; Schwarz et al., 2006; Stephens et al., 2003) coupled to an APEX-Q jet nebulizer (Elemental Scientific Inc., USA). Further analytical details regarding calibration, reproducibility and autosampling method can be found in Osmont et al. (2018). The samples were subsequently analysed for 13 ions (five cations: ammonium, $\mathrm{NH}_{4}^{+}$; calcium, $\mathrm{Ca}^{2+}$; magnesium, $\mathrm{Mg}^{2+}$; potassium, $\mathrm{K}^{+}$; and sodium, $\mathrm{Na}^{+}$; and eight anions: acetate,
$\mathrm{CH}_{3} \mathrm{COO}^{-}$; chloride, $\mathrm{Cl}^{-}$; fluoride, $\mathrm{F}^{-}$; formate, $\mathrm{HCOO}^{-}$; methanesulfonate, $\mathrm{MSA}, \mathrm{CH}_{3} \mathrm{SO}_{3}^{-}$; nitrate, $\mathrm{NO}_{3}^{-}$; oxalate, $\mathrm{C}_{2} \mathrm{O}_{4}^{2-}$; and sulfate, $\mathrm{SO}_{4}^{2-}$ ) by ion chromatography (850 Professional IC, Metrohm, Switzerland).

To estimate microscopic charcoal concentrations, we added a known amount of Lycopodium marker spores to the six snow samples dedicated to palynological analyses and prepared the samples following the evaporationbased protocol for ice samples developed by Brugger et al. (2018b). Microscopic charcoal particles were identified as completely opaque particles with a major axis $>10 \mu \mathrm{m}$ and with an angular shape following Tinner and $\mathrm{Hu}$ (2003). We counted a combined sum of 200 items (microscopic charcoal + Lycopodium spores; Finsinger and Tinner, 2005). 


\subsection{Air mass trajectories and transport simulations}

To link the observations in the snowpack with the fire emissions in Portugal, we calculated $5 \mathrm{~d}$ backward trajectories at a 6-hourly resolution with the Lagrangian analysis tool LAGRANTO (Sprenger and Wernli, 2015) based on ERAInterim reanalysis data (Dee et al., 2011). The trajectories started at the coordinates of JFJ, at 20 equidistant levels in pressure coordinates between 700 and $500 \mathrm{hPa}$, in accordance with the detected smoke plume height.

We used the global aerosol-climate model ECHAM6.3HAM2.3 to simulate the transport of BC and microscopic charcoal (Gilgen et al., 2018; Stier et al., 2005; Zhang et al., 2012). To the best of our knowledge, this is the only model with a charcoal module implemented. The large-scale wind velocities of the simulations were nudged towards ERAInterim reanalysis data. Two simulations were conducted: (i) a simulation without any fire emissions and (ii) a simulation including the fire emissions that occurred in central Portugal $\left(-8.45\right.$ to $-7.85^{\circ} \mathrm{E} ; 39.75$ to $\left.40.25^{\circ} \mathrm{N}\right)$ in June. Daily fire emission fluxes were calculated from the Fire Inventory from the National Center for Atmospheric Research (NCAR) (FINN version 1.6.; Wiedinmyer et al., 2011) and interpolated to the model grid. For anthropogenic aerosol emissions, we used ACCMIP (Atmospheric Chemistry and Climate Model Intercomparison Project) interpolated emissions for the year 2008 (Lamarque et al., 2010), being constant over the year. A spatial resolution of T127L95 was applied ( $\approx 100 \mathrm{~km}$ at the Equator). To simulate the microscopic charcoal particles, we chose a density of $0.6 \mathrm{~g} \mathrm{~cm}^{-3}$, a geometric mean radius upon emission of $5 \mu \mathrm{m}$, a threshold radius of $4.9 \mu \mathrm{m}$ and a scaling factor of BC mass emissions of 250 . These parameters were extensively tested, compared and validated by Gilgen et al. (2018).

\subsection{Satellite observations}

To analyse the fire source itself, i.e. the spatial and temporal extent as well as the intensity of the burning near Pedrógão Grande, we used different fire products retrieved from satellite imagery over the study area. The fires were detected by several satellite sensors and during multiple overpasses (e.g. Visible Infrared Imaging Radiometer Suite, VIIRS; Moderate Resolution Imaging Spectroradiometer, MODIS; or Advanced Very High Resolution Radiometer, AVHRR), which allows us to study the temporal evolution (i.e. progression) of the fires. In consistency with FINN v1.6, we chose the Thermal Anomalies and Fire Daily L3 Global product, which is also utilized for the emission model. In addition, we obtained the Burned Area Monthly L3 Global product of MODIS.

The MODIS sensors on board NASA's Earth Observing System Terra and Aqua satellites have a return period of 1 to $2 \mathrm{~d}$ with a daytime Equator crossing time at 10:30 (13:30) local time for Terra (Aqua). The areal extent of the study site was defined as -8.45 to $-7.85^{\circ}$ longitude and 39.75 to $40.25^{\circ}$ latitude according to the location of the forest fires and also used for the modelling (see Sect. 2.4). For June 2017, we downloaded the respective tiles over the study area of both products: (i) the $1 \mathrm{~km}$ daily thermal anomaly and fires MOD14A1 (MODIS/Terra) and MYD14A1 (MODIS/Aqua: both V006; Giglio et al., 2015a) products and (ii) the monthly $500 \mathrm{~m}$ Burned Area product MCD64A1 (V006; Giglio et al., $2015 b)$. The latter is a combined product of the burned area detected by the MODIS sensors onboard the Terra and Aqua satellites. It was resampled to a spatial resolution of $1 \mathrm{~km}$. The tiles of the MOD14A1 and MYD14A1 products were mosaicked into one image. We lastly reprojected the scenes of both products accordingly to the FINN emission data (version 1.6; Wiedinmyer et al., 2011). Both products were analysed in terms of active-fire progression, fire radiative power (FRP), burned area date and extent, and cloud coverage. Moreover, we compared them with the spatial distribution of emission species, like $\mathrm{BC}, \mathrm{NO}_{x}$ and $\mathrm{PM}_{2.5}$, derived from the FINN database.

To detect the fire plume, we analysed different daily aerosol optical depth (AOD) products: (1) OMAEROe v003 at $0.25^{\circ}$ (smallest spatial resolution in the GIOVANNI database) as well as the (2) MODIS/Terra (MOD04_L2) and MODIS/Aqua (MYD04_L2) product at $10 \mathrm{~km}$ spatial resolution (at nadir) for the study time period from 17 until 26 June.

\section{Results and discussions}

\subsection{Snow pit profile}

The snow pit profile (Fig. 2b) showed five layers with different grain size and density (Fig. 2c). Layer A, from 0 to $10 \mathrm{~cm}$ depth $\left(d=0.2 \mathrm{~g} \mathrm{~cm}^{-3}\right)$, was composed of fresh and very light powder snow corresponding to the snowfall on 29 June. Layer B, from 10 to $22 \mathrm{~cm}\left(d=0.37 \mathrm{~g} \mathrm{~cm}^{-3}\right)$, was made of light snow probably originating from the snowfall on 28 June. Snow in layer C, from 22 to $50 \mathrm{~cm}(d=$ $\left.0.54 \mathrm{~g} \mathrm{~cm}^{-3}\right)$, already experienced some transformation as bigger $(2-3 \mathrm{~mm})$ round-shaped grains were observed that could relate to the snowfalls that occurred on 25 and 26 June. For those days, a good agreement was obtained between the precipitation amount from Itramen and the snow layer height corrected for density (Fig. 2a), confirming our time attribution. Below $50 \mathrm{~cm}$ depth, accurate dating becomes impossible, but the frequent presence of ice layers and more compact snow indicates melting due to warmer temperatures. This is in line with the June 2017 heat wave in Switzerland that lasted from 19 to 24 June (MétéoSuisse, 2017). Layer $\mathrm{D}$, from 50 to $76 \mathrm{~cm}$ depth, was composed of denser and compact snow $\left(d=0.55 \mathrm{~g} \mathrm{~cm}^{-3}\right)$. Lastly, below $78 \mathrm{~cm}$ depth, layer E seemed even more compact, although the density did not significantly change $\left(d=0.52 \mathrm{~g} \mathrm{~cm}^{-3}\right)$. 


\subsection{Fire tracers: rBC, microscopic charcoal and major ions}

A peak with concentrations up to $9.8 \mathrm{ng} \mathrm{g}^{-1}$ is visible in the rBC profile (Fig. 2d) from 22 to $37 \mathrm{~cm}$ depth (samples 4 to 6 ; layer $\mathrm{C}$ ), corresponding to the first snowfalls recorded after the event. This suggests that atmospheric BC was probably scavenged by snow on 25 and 26 June, which is in agreement with a drop in atmospheric eBC concentration observed simultaneously (Fig. 2a). Wet deposition seems to be the preferential pathway as the rBC peak is spread over the whole accumulated snow layer, while dry deposition would rather create a thin and highly concentrated layer. Several studies indicate that $\mathrm{rBC}$ is mainly scavenged from the atmosphere via wet deposition processes (Cape et al., 2012; Ruppel et al., 2017; Sinha et al., 2018). The uppermost two layers (A-B, samples 1 to 3 ) show very low $\mathrm{rBC}$ concentrations (average: $0.21 \mathrm{ng} \mathrm{g}^{-1}$ ), in agreement with the clean atmospheric conditions that prevailed on 28 and 29 June with eBC concentrations below $10 \mathrm{ng} \mathrm{m}^{-3}$. Below the $\mathrm{rBC}$ peak, a secondary $\mathrm{rBC}$ maximum with $4.5 \mathrm{ng} \mathrm{g}^{-1}$ was observed between 60 and $70 \mathrm{~cm}$ in one replicate series, but otherwise average concentrations are low $\left(2.0 \mathrm{ng} \mathrm{g}^{-1}\right)$. Except for this secondary maximum, a very good agreement is obtained between the two series of replicate $\mathrm{rBC}$ samples ( $r=0.90$, all samples).

The microscopic charcoal record (Fig. 2e) shows a smaller peak at $60-70 \mathrm{~cm}$ depth (4000 fragments per litre), and the main maximum at $30-40 \mathrm{~cm}$ depth, reaching higher concentrations by a factor of 10 (20000 fragments per litre) compared to the average of all six samples. We relate the main peak to the fire event in Portugal. Compared to the rBC peak, the narrower microscopic charcoal peak could indicate a more important contribution of dry deposition versus wet deposition, consistent with its larger particle size $(>10 \mu \mathrm{m}$ major axis for microscopic charcoal vs. $<1 \mu$ m diameter for $\mathrm{rBC}$ ). Microscopic charcoal is a specific proxy for biomass burning, whereas $\mathrm{rBC}$ is less specific and can also originate from fossil fuel combustion. No ice layer was observed in the uppermost $50 \mathrm{~cm}$ of the snow pit, which indicates that both rBC and microscopic charcoal profiles were not affected by melting processes.

The mass size distribution for the broadband low gain (BBLG) channel of the SP2 remained similar throughout the profile, with 306 and $291 \mathrm{~nm}$ for the two series of replicates, respectively (Fig. 2d). This indicates that $\mathrm{rBC}$ size distributions in the falling snow are rather stable, as already observed by Sinha et al. (2018). Only sample 13 shows a bigger fraction of large $\mathrm{rBC}$ particles, in association with a small peak in $\mathrm{rBC}$ and charcoal concentration. In contrast, no shift in the $\mathrm{rBC}$ size distribution is visible for samples 4 to 6 during the peak in $\mathrm{rBC}$ and charcoal concentrations.

Continental-scale calibrations comparing satellite-based fire incidence and charcoal influx into lake sediment or peat bogs suggest that microscopic charcoal particles $>10 \mu \mathrm{m}$ mainly originate from regional sources with an average ra- dius of ca. $40 \mathrm{~km}$ (Adolf et al., 2018). However, previous studies of charcoal in ice cores indicate that charcoal can be transported over distances larger than $500 \mathrm{~km}$ (e.g. Brugger et al., 2018a; Eichler et al., 2011; Reese et al., 2013, Hicks and Isaksson, 2006). These differences can be explained by dissimilar environmental conditions as lake sediment and peat bog studies are usually performed at low-elevation sites surrounded by potential burning sources, while snow pits and ice cores originate from high-latitude or high-altitude sites away from vegetation (Brugger et al., 2018a, 2019b). These remote sites frequently lie within the free troposphere: for JFJ, free-troposphere background conditions are observed about $39 \%$ of the time, with a maximum of $60 \%$, in winter, and a minimum of $20 \%$, in summer (Bukowiecki et al., 2016). However, a travel distance from Portugal to JFJ of around $1500 \mathrm{~km}$ seems exceptional. Given the strong intensity of this fire (see Sect. 3.5), we hypothesize that convection lifted a large amount of microscopic charcoal particles high up in the atmosphere, enabling the long-distance travel. The microscopic charcoal peak concentrations observed in this study are outstandingly high and only comparable to exceptional peak events in other ice cores (Brugger et al., 2018a; Eichler et al., 2011; Reese et al., 2013), which might be due partly to the highly resolved sampling. This is in contrast to rBC, for which such peak concentrations have been observed in the pre-industrial part of $\mathrm{Eu}-$ ropean high-altitude ice cores, when $\mathrm{rBC}$ mainly originated from biomass burning (Lim et al., 2017; Sigl et al., 2018).

In addition to $\mathrm{rBC}$ and charcoal, ions such as ammonium $\left(\mathrm{NH}_{4}^{+}\right)$, formate $\left(\mathrm{HCOO}^{-}\right)$, acetate $\left(\mathrm{CH}_{3} \mathrm{COO}^{-}\right)$and nitrate $\left(\mathrm{NO}_{3}^{-}\right)$have been used as fire tracers (Arienzo et al., 2017; Fischer et al., 2015; Legrand et al., 2016; Savarino and Legrand, 1998), although other emission sources exist, such as direct biogenic emissions (ammonium, formate), oxidation from volatile organic compounds (formate, acetate) and anthropogenic sources (agriculture for ammonium, traffic and agriculture for nitrate). Except for a few values, a good agreement was obtained between the two sets of replicates of the major ion profiles, particularly for ammonium and nitrate (Fig. 3). None of the ionic fire tracers shows increased concentrations at the depth of the rBC peak (22$37 \mathrm{~cm})$. We hypothesize that charcoal originating from the Portugal fires was deposited by dry deposition during the period 22 to 24 June, when the fire plume arrived at the JFJ as detected by elevated atmospheric eBC concentrations. Since no snowfall occurred during that period, the majority of BC was not deposited. Dry deposition most likely resulted in a confined charcoal layer, which was not separated from the rBC peak in the snow pit due to the coarse sampling resolution of $10 \mathrm{~cm}$. With the beginning of snowfall on 25 June, air mass transport changed, ending the advection of the fire plume to the JFJ as indicated by backward trajectories (see below and Fig. 4). Instead more regional, polluted air masses were scavenged, which explains the absence of ionic fire tracers and of a shift in the $\mathrm{rBC}$ size distribution. 

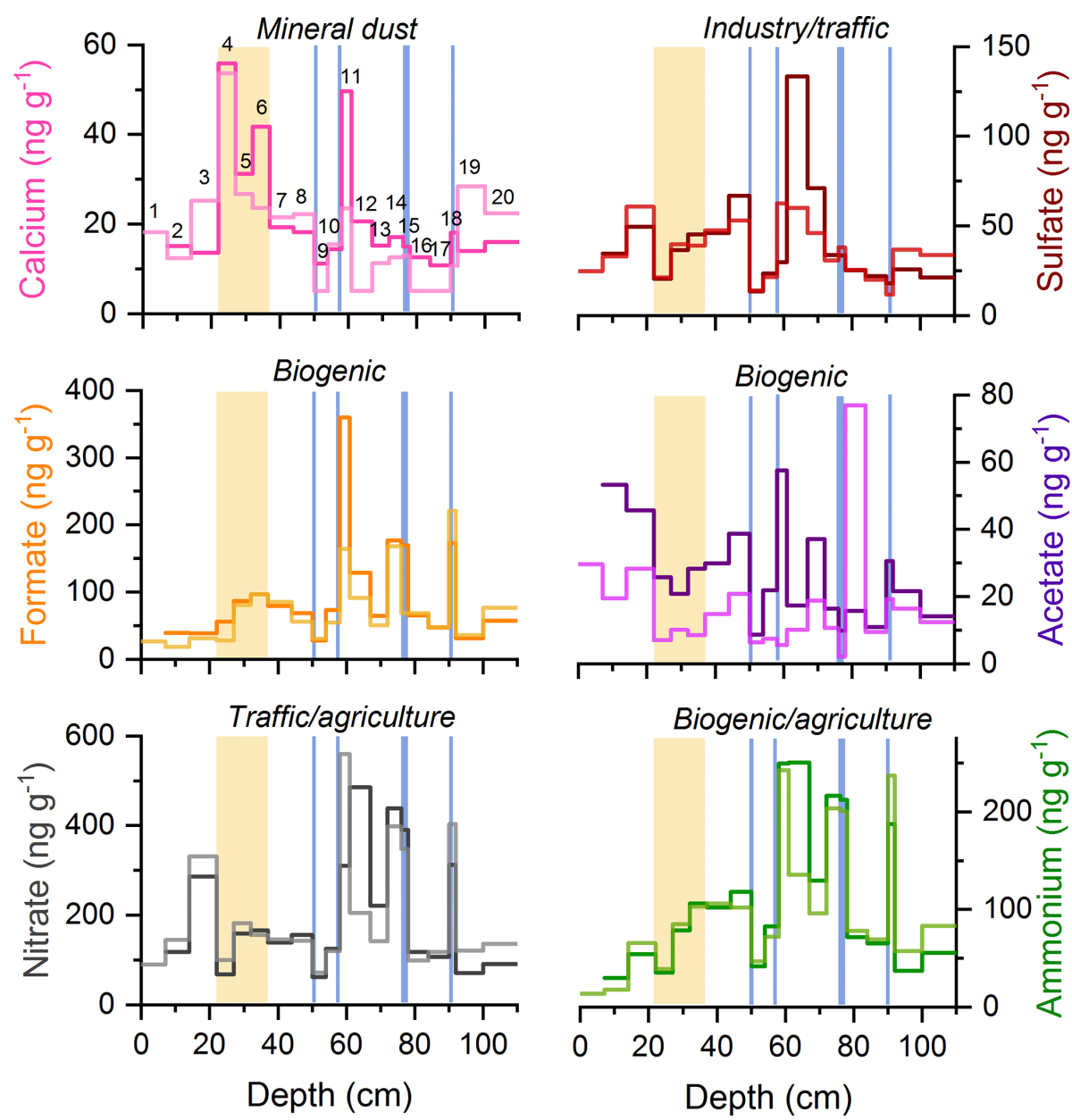

Figure 3. Ionic records from the Jungfraujoch snow pit with the two sets of replicates (darker and lighter lines). The orange bar indicates the depth at which rBC and microscopic charcoal peaks are observed. Blue bars represent ice layers. Sample numbers are specified for calcium and are similar for the other ions. Potential sources are indicated above each graph.

\section{3 rBC scavenging ratios}

The $\mathrm{rBC}$ scavenging ratios $(W)$ were calculated to determine the total scavenging of $\mathrm{rBC}$ from air to snow by snowfall, based on the following formula:

$W=\rho C_{\mathrm{s}} / C_{\mathrm{a}}$,

with $\rho$ the air density in grams per cubic metre, $C_{\mathrm{s}}$ the concentration of $\mathrm{rBC}$ in snow in nanograms per gram and $C_{\mathrm{a}}$ the concentration of $\mathrm{rBC}$ in air in nanograms per cubic metre (Schwikowski et al., 1995). For $C_{\mathrm{a}}$, we considered the daily average $\mathrm{eBC}$ concentration on 24 June, just before the precipitation starts, while for $C_{\mathrm{s}}$, we used the average of samples 4-6 of the snow pit, corresponding to the days 25 and 26 June, when peak values are found. The air density at JFJ of $842 \mathrm{~g} \mathrm{~m}^{-3}$ was calculated with the ideal gas law using a temperature of $273.15 \mathrm{~K}$ and a pressure of $66000 \mathrm{~Pa}$ obtained from MeteoSwiss for the JFJ weather station.

In our case, the calculation of $\mathrm{rBC}$ scavenging ratios (Table 1) is highly dependent on the choice of a mass absorp- tion coefficient (MAC) for converting the light absorption intensity given by the MAAP into an eBC concentration. The objective is that the $\mathrm{eBC}$ mass concentrations from the MAAP precisely match the $\mathrm{rBC}$ mass concentrations from the SP2 in order to not introduce a methodological bias as two different quantification methods are used. Previous studies suggested a median MAC of $10.2 \pm 3.2 \mathrm{~m}^{2} \mathrm{~g}^{-1}$ for JFJ (Liu et al., 2010) or $11.1 \pm 0.2 \mathrm{~m}^{2} \mathrm{~g}^{-1}$ in summer (Cozic et al., 2008). Higher values $\left(13.3 \pm 3.0 \mathrm{~m}^{2} \mathrm{~g}^{-1}\right)$ have also been reported in the case of eBC from a purely biomass burning origin (Schwarz et al., 2008). An upper limit estimate of $20 \mathrm{~m}^{2} \mathrm{~g}^{-1}$ for the MAC was obtained during the 2016 summer campaign of the CLoud and Aerosol Characterization Experiments (CLACE) at JFJ (Motos et al., 2019). This value is of particular interest as both an MAAP and an SP2 were simultaneously sampling the air at JFJ during this campaign. By applying a MAC of $20 \mathrm{~m}^{2} \mathrm{~g}^{-1}$, a perfect agreement could be obtained between the $\mathrm{BC}$ mass concentrations given by the MAAP and those given by SP2 (measurements not 

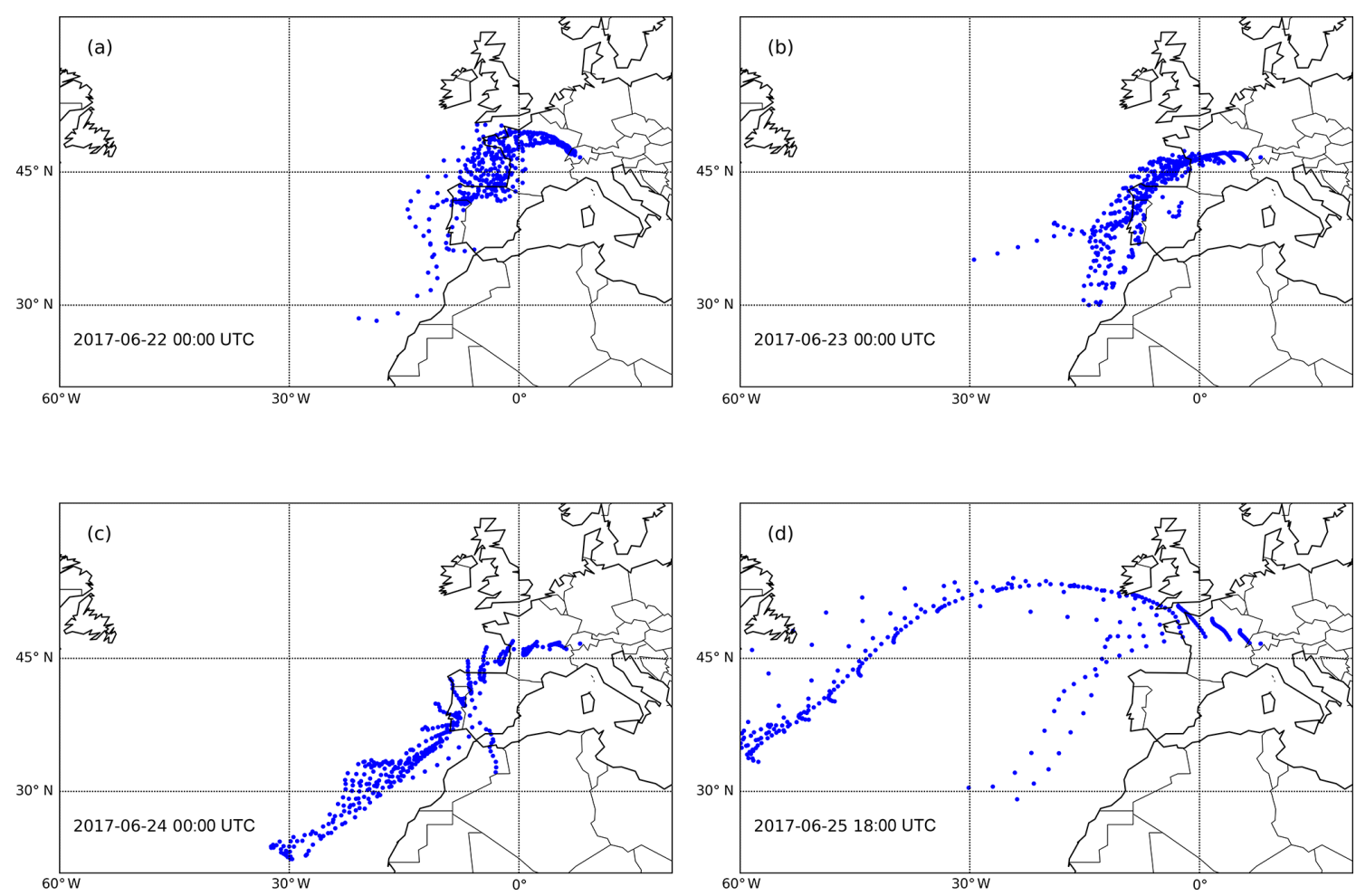

Figure 4. Air mass trajectories calculated $5 \mathrm{~d}$ backward starting from the Jungfraujoch site at 00:00 UTC from 22 to 24 June 2017 . For 25 June, starting time is 18:00 UTC.

Table 1. Values used for the calculation of $\mathrm{rBC}$ scavenging ratios $(W)$ at Jungfraujoch, Switzerland. For air concentration $\left(C_{\mathrm{a}}\right)$, the eBC average value of 24 June was used under two different MACs. For snow concentration $\left(C_{\mathrm{S}}\right)$, concentrations from the two sets of replicates were used.

\begin{tabular}{lrrr}
\hline MAC $\left(\mathrm{m}^{2} \mathrm{~g}^{-1}\right)$ & $C_{\mathrm{a}}\left(\mathrm{ng} \mathrm{m}^{-3}\right)$ & $C_{\mathrm{s}}\left(\mathrm{ng} \mathrm{g}^{-1}\right)$ & $W$ \\
\hline 10 & 147.5 & $7.14-8.01$ & $41-46$ \\
20 & 73.8 & $7.14-8.01$ & $81-91$
\end{tabular}

shown). Therefore, MACs of 10 and $20 \mathrm{~m}^{2} \mathrm{~g}^{-1}$ were chosen here $(\lambda=637 \mathrm{~nm})$ to test the lower and upper limits, leading to a range of scavenging ratios from 41 to 91 (Table 1).

Few BC air-to-snow scavenging ratio values are available in the literature, usually ranging from 100 to 150 (Table 2). By comparing our scavenging ratios obtained at JFJ with values from previous studies, it appears that the choice of a MAC value of $20 \mathrm{~m}^{2} \mathrm{~g}^{-1}$ seems preferable. Discrepancies can arise from the different locations implying various climatic conditions, from the use of different methods to quantify BC (light absorption, thermal-optical or incandescence), and from the different relative contribution of wet and dry deposition processes, depending on the location and elevation, with higher scavenging ratios at higher altitudes (Gogoi et al., 2018).

\subsection{Atmospheric transport}

The $5 \mathrm{~d}$ air mass backward trajectory analyses suggest Portugal as a very likely source for the atmospheric eBC (Fig. 4). For all the days between 22 and 24 June, when atmospheric eBC concentrations were high, part of the air masses originated from Portugal, which is also supported by simulations from MeteoSwiss (MeteoSwiss, 2017). The back trajectories with arrival at JFJ on 25 June at 18:00 UTC indicate a major change in the synoptic situation to more northwesterly flow directions. We can only speculate that this happened concomitant with the onset of precipitation since the timing of the latter is not precisely known. AOD data at $10 \mathrm{~km}$ resolution suggest that, between 20 and 22 June, the JFJ site received air masses with elevated AOD from Portugal. The AOD levels increased over Switzerland, mainly north of the Alps, during that time, in agreement with the backward trajectories (Fig. 4). From 23 to 25 June the area was cloud-covered, so AOD could not be retrieved. Simulations with ECHAM-HAM show no clear difference for BC when we compare the simulation with fires to the simulation without fires (Fig. 5). In our simulations, BC is preferentially removed by wet scavenging. This suggests that the simulated BC deposition peak observed from 26 to 28 June mainly reflects the precipitation pattern. Furthermore, other $\mathrm{BC}$ sources than fires seem to dominate in our simulations, which is in agreement with our hypothesis that during fire 
Table 2. Examples of BC scavenging ratios available in the literature.

\begin{tabular}{lrll}
\hline Location & $W$ & $\begin{array}{l}\text { BC measurement } \\
\text { quantity }\end{array}$ & Authors \\
\hline Jungfraujoch (JFJ) & $81-91$ & rBC/eBC & This study \\
Arctic & 160 & eBC & Clarke and Noone (1985) \\
Abisko, Sweden & $97 \pm 34$ & eBC & Noone and Clarke (1988) \\
Antarctica & 150 & eBC & Warren and Clarke (1990) \\
NE China? & $140 \pm 100$ & EC & Wang et al. (2014) \\
Svalbard & $98 \pm 46$ & eBC & Gogoi et al. (2016) \\
Antarctic & $120 \pm 23$ & eBC & Gogoi et al. (2018) \\
Global & 125 & Modelled & Jacobson (2004) \\
\hline
\end{tabular}

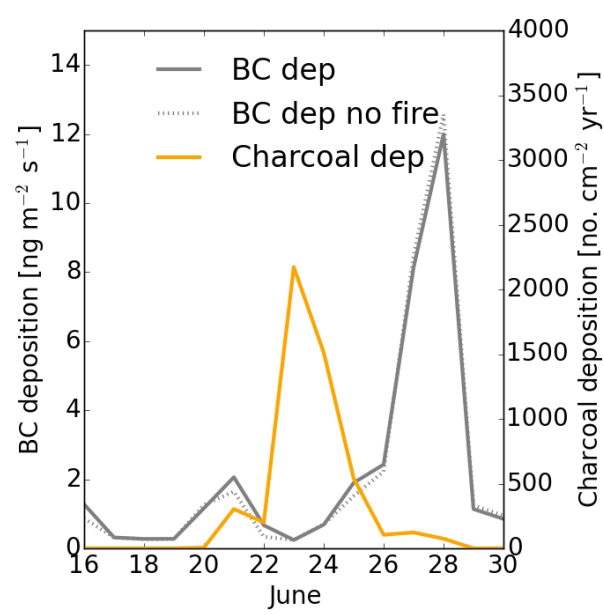

Figure 5. Simulated deposition fluxes of BC and microscopic charcoal at Jungfraujoch. In line with the observations, the deposition (dep) fluxes for BC are given as mass fluxes, whereas the deposition fluxes of microscopic charcoal are given as the flux of the number of particles larger than a certain threshold ( $10 \mu \mathrm{m}$ major axis). For BC, a simulation without fire emissions (dotted grey line) and a simulation including the fire emissions near Pedrógão Grande in central Portugal (solid grey line) are shown. For microscopic charcoal, only the simulation including fire emissions (solid orange line) is shown since biomass burning is the only source of microscopic charcoal.

plume arrival at JFJ the majority of fire-related BC was not deposited due to the lack of snowfall. With the beginning of snowfall at JFJ, air mass transport changed, and more regional polluted air masses with minor or without fire contribution were scavenged. In addition, the relatively low spatial resolution of the model smooths the topography, resulting in a more efficient vertical mixing in the lower troposphere. As a consequence, overestimated levels of $\mathrm{BC}$ from regional anthropogenic sources can probably reach the location of JFJ in the model compared to reality.

Microscopic charcoal has no other sources than biomass burning in our model. We observe a clear peak in the deposited microscopic charcoal fluxes on 23 June (Fig. 5), which is predominantly caused by dry removal processes (i.e. dry deposition and gravitational settling), and near the observed peak on 22 June for atmospheric eBC (Fig. 2a). The simulated deposition fluxes are still rather high on 25 June, suggesting that dry deposition continued for the entire fire episode at JFJ. An exact temporal match cannot be expected due to the daily resolution of the fire emissions and the rather low spatial resolution of the model together with the dating uncertainties of the snow pit. Nevertheless, this result qualitatively confirms the hypothesis that the microscopic charcoal particles observed at JFJ originated from Portugal.

\subsection{Observations by satellites}

Quantification of the occurrence (active fires), intensity (maximum FRP) and extent (burned area) provided by satellite products allows the modelling of biomass burning emissions. Here, we analysed the temporal and spatial extent as well as the FRP of the wildfires with the MODIS thermal anomaly and fire (MOD14A1 and MYD14A1) and the MCD64A1 Burned Area products together with emission species of the FINN v1.6. database. The fires evolved on 17 June 2017 in the afternoon (Fig. 6a) in a central location between the fire clusters. An additional comparison of the MODIS/Aqua and VIIRS Active Fire product (375 m spatial resolution; Schroeder et al., 2014) showed that the fire was detected by the VIIRS Active Fire product at $\sim$ 13:46 UTC. The fire was located a few kilometres away from a thick cumulonimbus cloud. Although the overpass time of MODIS/Aqua was almost simultaneous (i.e. 13:4513:50 UTC), the fire was too small to be detected by the coarser-spatial-resolution sensor $(1 \mathrm{~km})$. This explains why FINN v1.6 has no emission entries for 17 June. Later during the day, several fires were already burning according to the Burned Area product, which indicates a fast spread in the south- and northward direction. Clouds obscured observation by the MODIS sensor on 18 June. Therefore, fewer active fires and lower maximum FRP were detected on this day, resulting in gaps in the MOD14A1 and MYD14A1 product (Fig. 6a). However, the MCD64A1 Burned Area product shows the day-by-day evolution of the fires, forming two big fires clusters. The maximum fire activity and vegetation con- 
Table 3. Burned area and BC emissions per day for the June 2017 forest fire in Portugal (* cloud covered).

\begin{tabular}{lrr}
\hline Day & Burned area $\left(\mathrm{km}^{2}\right)$ & BC emissions $(\mathrm{t})$ \\
\hline 17 June & 13 & - \\
18 June & $148^{*}$ & 53.7 \\
19 June & 243 & 99.8 \\
20 June & 45 & 25.5 \\
21 June & 30 & 24.5 \\
22 June & 19 & - \\
23 June & 3 & - \\
\hline Total & 501 & 203.5 \\
\hline
\end{tabular}

sumption was observed on 19 and 20 June, as indicated by the burned area and the high maximum FRP values. Less powerful fires on the south and mainly north edges of the two fire clusters burned from 20 to 22 June until the fires were completely extinguished on 24 June.

The total area burned over these days accumulates to $501 \mathrm{~km}^{2}$ according to the Burned Area product. The total area might be underestimated by this product compared to the maximum FRP, which indicates a larger spatial extent of burning. The detection signals of the burned area were probably too low to detect the burned area along the outer edges of the fires in the south and north (Fig. 6a). Nevertheless, this area agrees well with the actual burned area of $470 \mathrm{~km}^{2}$ for the two major fire outbreaks occurring in the municipalities of Pedrógão Grande and Góis based on ground observations (CTI, 2017). The modelled BC emissions (Fig. 6b), based on the FINN v1.6. database, range from less than 500 to over $2250 \mathrm{~kg} \mathrm{~d}^{-1} \mathrm{px}^{-1}$. A total of about $203.5 \mathrm{t}$ of BC was emitted by this exceptional fire event (Table 3). Due to cloud obscuration and masking on 18 June, this value is probably underestimated.

\subsection{Deposition fluxes}

Deposition fluxes were calculated for $\mathrm{rBC}$ and microscopic charcoal by multiplying the concentration of the respective compounds by the snow accumulation corrected for density. Even if these values remain uncertain due to dating limitations of the snow pit and to the lack of detailed snowfall monitoring at JFJ, preventing us from knowing the exact duration of a snowfall event, they constitute the first step towards a quantitative transfer function.

For microscopic charcoal, we observed a total deposition flux of 104 fragments per square centimetre in the snow pit, around 8 times more than the modelled flux of 13.8 fragments per square centimetre (integral over 23 and 24 June; Fig. 5). Compared to yearly average fluxes from high-alpine ice archives (Table 4), the estimated influx at JFJ during the event is exceptional and cannot be explained by the somewhat lower altitude of the JFJ site compared to the other alpine ice-core locations. The comparison suggests this single outstanding event deposited nearly as many charcoal particles as during an average year in other ice archives (e.g. Brugger et al., 2018a).

For rBC, the total deposition flux for samples 4, 5 and 6 was $62 \mathrm{ng} \mathrm{cm}^{-2}$ (average of replicate samples). The integral flux retrieved from the model for 26-28 June is $195 \mathrm{ng} \mathrm{cm}^{-2}$ (Fig. 5), a factor of 3 higher than the observation. Interestingly, the model underestimates the charcoal and overestimates the BC flux. When the model performance was evaluated previously with longer-term charcoal deposition fluxes, the opposite was observed (Gilgen et al., 2018). It was hypothesized that the model overestimates the fluxes at ice-core sites because of their high location within complex topography. The model is not able to simulate these high locations correctly since the surface altitude is constant over the whole grid box; i.e. the topography is smoothed. In addition, icecore sites are often located above the top plume height of most fires (Rémy et al., 2017), which may prevent transport of charcoal particles to them. Obviously the Pedrógão Grande case was exceptional since the plume was transported at elevations between 3000 and $5000 \mathrm{~m}$ a.s.l. In addition, an underestimation of the fire emissions might have played a role for the charcoal flux. Contrary to the effect on charcoal, the smoothed topography in the model and the corresponding more efficient vertical mixing might have resulted in overestimated levels of $\mathrm{BC}$ from regional anthropogenic sources, explaining the overestimation of the BC flux. Large discrepancies between modelled and actual deposited rBC fluxes were already pointed out by Thomas et al. (2017), who found a factor of 2-100 in a case study from Greenland and advocated for a better description of precipitation scavenging and fire emissions by the models.

\section{Conclusions}

In this case study, biomass burning emissions from an outstanding fire event in Portugal in June 2017 were observed at the high-alpine site Jungfraujoch, Swiss Alps, in both the atmosphere and the snowpack. According to satellite observations, the fire burned a total area of $501 \mathrm{~km}^{2}$ from 17 to 24 June, in close agreement with ground observations. At least about $203.5 \mathrm{t}$ of $\mathrm{BC}$ were emitted during this event. Atmospheric backward trajectory analyses showed that the resulting plume of smoke travelled $3 \mathrm{~d}$ before reaching Switzerland, leading to a peak in atmospheric $\mathrm{eBC}$ at JFJ on 22 June and lasting until 25 June, when snowfall occurred. Dry deposition of microscopic charcoal resulted in an outstanding peak in the snowpack. This event deposited nearly as many charcoal particles as during an average year in other ice archives. Our study highlights that, for microscopic charcoal, snow and ice archives are more sensitive to distant fires than sedimentary archives due to the special settings at high elevation. For snow and ice archives, it also reveals that a 

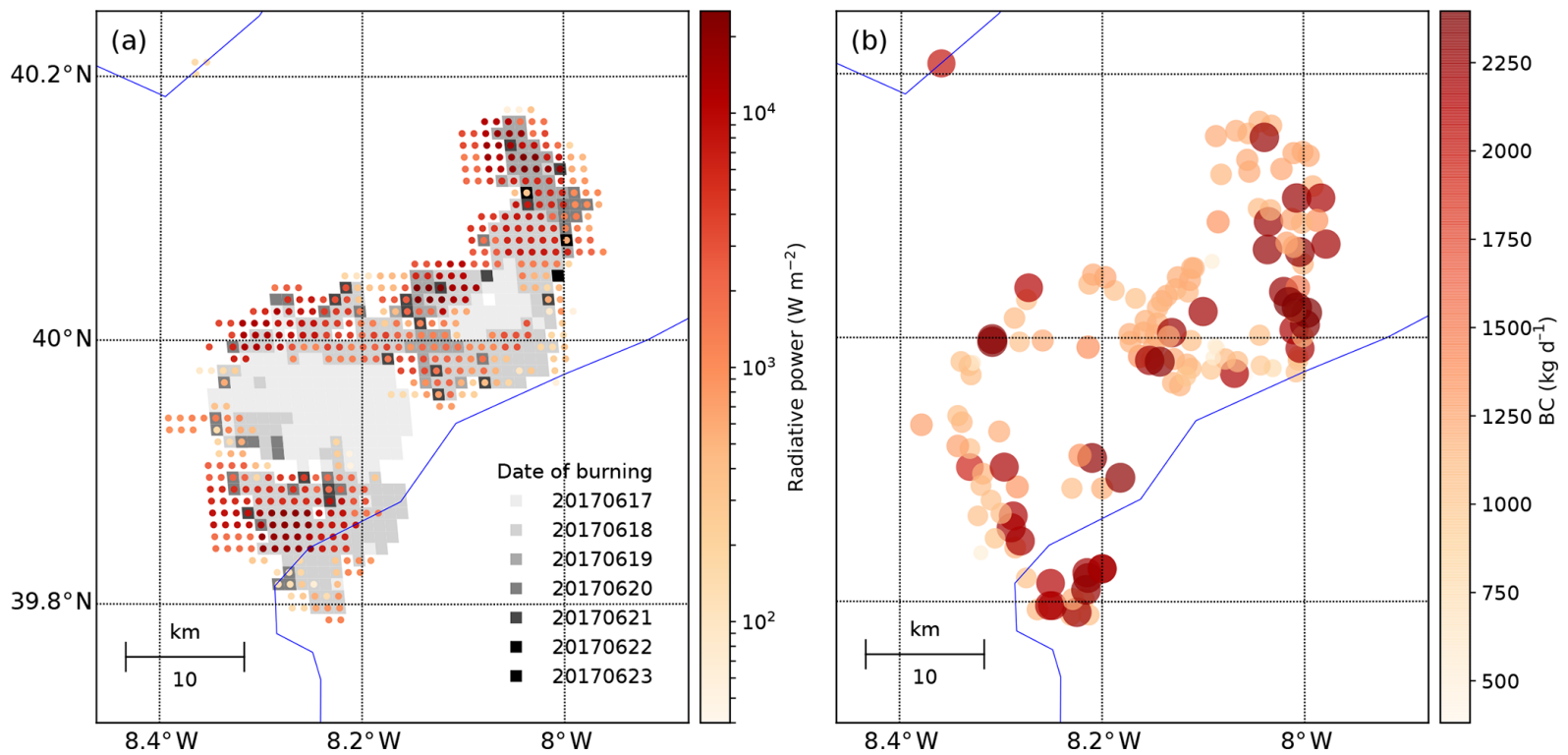

Figure 6. Spatially and temporally observed wild fires and their BC emissions near Pedrógão Grande, Portugal, for 17 to 23 June at 1 km spatial resolution. (a) Date of the area burned (MCD64A1) and maximum fire radiative power (FRP) values of the active fires according to MOD14A1 and MYD14A1, showing the evolved two fire clusters. (b) Corresponding BC emission values based on the FINN v1.6 database with high values at the outer edges.

Table 4. Comparison of microscopic charcoal influx at Jungfraujoch with the yearly average influx at selected glacier sites based on identical laboratory preparation and analytical methods.

\begin{tabular}{lcrl}
\hline Site & $\begin{array}{r}\text { Altitude } \\
\text { (m a.s.l.) }\end{array}$ & $\begin{array}{r}\text { Microscopic charcoal influx } \\
\text { (fragments per square centimetre per year) }\end{array}$ & Reference \\
\hline Jungfraujoch & 3560 & $104^{*}$ & This study \\
Tsambagarav (Mongolian Altai) & 4100 & 200 & Brugger et al. (2018a) \\
Colle Gnifetti (Swiss Alps) & 4500 & 390 & Gilgen et al. (2018) \\
Summit (central Greenland) & 3200 & 9 & Brugger et al. (2019b) \\
Illimani (Bolivian Andes) & 6300 & 130 & Brugger et al. (2019a) \\
\hline
\end{tabular}

* This event only in fragments per $\mathrm{cm}^{2}$.

much longer travelling distance $(\approx 1500 \mathrm{~km})$ than previously thought can be reached, with outstandingly high concentrations in the case of events with optimal weather and transport conditions, thus making microscopic charcoal an excellent biomass burning tracer in ice archives. For rBC, in contrast, concentrations in the snow were not exceptionally high. In combination with the absence of a peak in ionic fire tracers such as ammonium, this suggests that the majority of atmospheric $\mathrm{BC}$ was not deposited during the fire episode due to a lack of precipitation. Instead the observed $\mathrm{rBC}$ peak was most likely caused by scavenging of air masses containing regional pollution with the beginning of snowfall on 25 June, which ended the advection of the fire plume to the JFJ. The $\mathrm{rBC}$ scavenging ratios were in line with previous studies, giving additional evidence that $\mathrm{rBC}$ was predominantly scavenged by wet deposition. Simulations with a global aerosolclimate model suggested that the observed microscopic char- coal particles originated from the fires in Portugal, whereas their contribution to the $\mathrm{BC}$ signal in snow was minor. The findings of our case study are important for future ice-core studies as they document that, for BC as a fire tracer, the signal preservation depends on precipitation and wet deposition. Single events, like this example, might not be preserved due to unfavourable meteorological conditions. Nevertheless, an exhaustive quantification of the process remains challenging due to the intrinsic uncertainties of each parameter, which requires further collaboration between the different disciplines involved.

Data availability. The data underlying Figs. 2 and 3 are available in the Supplement. 
Supplement. The supplement related to this article is available online at: https://doi.org/10.5194/tc-14-3731-2020-supplement.

Author contributions. DO designed the project, carried out sampling, performed rBC analyses and wrote the paper. SB performed microscopic charcoal analyses and contributed to the manuscript writing. AG made atmospheric transport simulations and contributed to the manuscript writing. HW retrieved and analysed satellite data and contributed to the manuscript writing. MiS organized and led the snow pit study and commented on the manuscript. RLM provided the eBC data from JFJ and advice to interpret them and commented on the manuscript. CS, WT and SW contributed to the manuscript writing. MaS led the project and contributed to and supervised the writing of the manuscript.

Competing interests. The authors declare that they have no conflict of interest.

Acknowledgements. We thank the Swiss National Science Foundation (SNF) for granting the Sinergia project "Paleo fires from highalpine ice cores", which funded this research (CRSII2_154450). Furthermore, we thank Nicolas Bukowiecki for providing the atmospheric eBC data from Jungfraujoch, the Institute for Snow and Avalanche Research (SLF) for the precipitation data, and Sabina Brütsch for ion chromatography analyses. The online eBC measurements at Jungfraujoch were conducted with financial support from MeteoSwiss (GAW-CH aerosol-monitoring programme) and from the European Union as well as the Swiss State Secretariat for Education, Research and Innovation (SERI) for the European Research Infrastructure for the observation of Aerosol, Clouds and Trace Gases (ACTRIS). The International Foundation High Altitude Research Station Jungfraujoch and Gornergrat (HSFJG) is acknowledged for hosting the online aerosol measurements and for giving access for snow sampling. The authors gratefully acknowledge the personal communication and data provided by Christine Wiedinmyer, Cooperative Institute for Research and Environmental Sciences (CIRES), University of Colorado Boulder, Boulder, CO, USA. The modelling was supported by a grant from the Swiss National Supercomputing Centre (CSCS) under project ID s652. The ECHAM-HAMMOZ model was developed by a consortium composed of ETH Zürich, Max Planck Institut für Meteorologie, Forschungszentrum Jülich, the University of Oxford, the Finnish Meteorological Institute and the Leibniz Institute for Tropospheric Research and managed by the Center for Climate Systems Modeling (C2SM) at ETH Zürich. The MOD14A1 and MYD14A1 as well as MCD64A1 data products were retrieved from the online Data Pool, courtesy of the NASA Land Processes Distributed Active Archive Center (LP DAAC), USGS/Earth Resources Observation and Science (EROS) Center, Sioux Falls, SD, USA (https://lpdaac.usgs.gov/data/), last access: 10 January 2020.

Financial support. This research has been supported by the Schweizerischer Nationalfonds zur Förderung der Wissenschaftlichen Forschung (grant no. 154450).
Review statement. This paper was edited by Joel Savarino and reviewed by two anonymous referees.

\section{References}

Adolf, C., Wunderle, S., Colombaroli, D., Weber, H., Gobet, E., Heiri, O., van Leeuwen, J. F. N., Bigler, C., Connor, S. E., Gałka, M., La Mantia, T., Makhortykh, S., Svitavská-Svobodová, H., Vannière, B., and Tinner, W.: The sedimentary and remotesensing reflection of biomass burning in Europe, Global Ecol. Biogeogr., 27, 199-212, 2018.

Andreae, M. O. and Merlet, P.: Emission of trace gases and aerosols from biomass burning, Global Biogeochem. Cy., 15, 955-966, 2001.

Arienzo, M. M., McConnell, J. R., Murphy, L. N., Chellman, N., Das, S., Kipfstuhl, S., and Mulvaney, R.: Holocene black carbon in Antarctica paralleled Southern Hemisphere climate, J. Geophys. Res.-Atmos., 6713-6728, https://doi.org/10.1002/2017JD026599, 2017.

Baltensperger, U., Gäggeler, H. W., Jost, D. T., Lugauer, M., Schwikowski, M., and Weingartner, E.: Aerosol climatology at the high-alpine site Jungfraujoch, Switzerland, J. Geophys. Res., 102, 19707-19715, 1997.

Bond, W. J., Woodward, F. I., and Midgley, G. F.: The global distribution of ecosystems in a world without fire, New Phytol., 165, 525-537, 2005.

Bowman, D. M. J. S., Balch, J. K., Artaxo, P., Bond, W. J., Carlson, J. M., Cochrane, M. A., D’Antonio, C. M., DeFries, R. S., Doyle, J. C., Harrison, S. P., Johnston, F. H., Keeley, J. E., Krawchuk, M. A., Kull, C. A., Marston, J. B., Moritz, M. A., Prentice, I. C., Roos, C. I., Scott, A. C., Swetnam , T. W., van der Werf, G. R., and Pyne, S. J.: Fire in the Earth System, Science, 324, 481-484, 2009.

Bowman, D. M. J. S., Balch, J. K., Artaxo, P., Bond, W. J., Cochrane, M. A., D’Antonio, C. M., DeFries, R. S., Johnston, F. H., Keeley, J. E., Krawchuk, M. A., Kull, C. A., Mack, M., Moritz, M. A., Pyne, S. J., Roos, C. I., Scott, A. C., Sodhi, N. S., and Swetnam, T. W.: The human dimension of fire regimes on Earth, J. Biogeogr., 38, 2223-2236, 2011.

Brugger, S. O., Gobet, E., Sigl, M., Osmont, D., Papina, T., Rudaya, N., Schwikowski, M., and Tinner, W.: Ice records provide new insights into climatic vulnerability of Central Asian forest and steppe communities, Global Planet. Change, 169, 188-201, 2018a.

Brugger, S. O., Gobet, E., Schanz, F. R., Heiri, O., Schwörer, C., Sigl, M., Schwikowski, M., and Tinner, W.: A quantitative comparison of microfossil extraction methods from ice cores, J. Glaciol., 64, 432-442, 2018b.

Brugger, S. O., Gobet, E., Osmont, D., Behling, H., Fontana, S. L., Hooghiemstra, H., Morales-Molino, C., Sigl, M., Schwikowski, M., and Tinner, W.: Tropical Andean glacier reveals colonial legacy in modern mountain ecosystems, Quaternary Sci. Rev., 220, 1-13, https://doi.org/10.1016/j.quascirev.2019.06.032, 2019a.

Brugger, S. O., Gobet, E., Blunier, T., Morales-Molino, C., Lotter, A. F., Fischer, H., Schwikowski, M., and Tinner, W.: Palynological insights into global change impacts on Arctic vegetation, fire, 
and pollution recorded in Central Greenland ice, Holocene, 29, 1189-1197, 2019b.

Bukowiecki, N., Weingartner, E., Gysel, M., Collaud Coen, M., Zieger, P., Herrmann, E., Steinbacher, M., Gäggeler, H. W., and Baltensperger, U.: A review of more than 20 years of aerosol observation at the high altitude research station Jungfraujoch, Switzerland (3580 m a.s.1.), Aerosol Air Qual. Res., 16, 764-788, 2016.

Cape, J. N., Coyle, M., and Dumitrean, P.: The atmospheric lifetime of black carbon, Atmos. Environ., 59, 256-263, 2012.

Clarke, A. D. and Noone, K. J.: Soot in the Arctic snowpack: a cause for perturbations in radiative transfer, Atmos. Environ., 19, 2045-2053, 1985.

Cozic, J., Verheggen, B., Weingartner, E., Crosier, J., Bower, K. N., Flynn, M., Coe, H., Henning, S., Steinbacher, M., Henne, S., Collaud Coen, M., Petzold, A., and Baltensperger, U.: Chemical composition of free tropospheric aerosol for $\mathrm{PM}_{1}$ and coarse mode at the high alpine site Jungfraujoch, Atmos. Chem. Phys., 8, 407-423, https://doi.org/10.5194/acp-8-407-2008, 2008.

CTI - Comissão Técnica Independente: Análise e apuramento dos factos relativos aos incêndios que ocorreram em Pedrógão Grande, Castanheira de Pera, Ansião, Alvaiázere, Figueiró dos Vinhos, Arganil, Góis, Penela, Pampilhosa da Serra, Oleiros e Sertã, entre 17 e 24 de junho de 2017, Relatório, Assembleia da República, p. 296, 2017.

Dee, D. P., Uppala, S. M., Simmons, A. J., Berrisford, P., Poli, P., Kobayashi, S., Andrae, U., Balmaseda, M. A., Balsamo, G., Bauer, P., Bechtold, P., Beljaars, A. C., van de Berg, L., Bidlot, J., Bormann, N., Delsol, C., Dragani, R., Fuentes, M., Geer, A. J., Haimberger, L., Healy, S. B., Hersbach, H., Hólm, E. V., Isaksen, L., Kållberg, P., Köhler, M., Matricardi, M., McNally, A. P., Monge-Sanz, B. M., Morcrette, J., Park, B., Peubey, C., de Rosnay, P., Tavolato, C., Thépaut, J., and Vitart, F.: The ERA-Interim reanalysis: configuration and performance of the data assimilation system, Q. J. R. Meteorol. Soc., 137, 553-597, 2011.

Dibb, J. E., Talbot, R. W., Whitlow, S. I., Shipham, M. C., Winterle, J., McConnell, J., and Bales, R.: Biomass burning signatures in the atmosphere and snow at Summit, Greenland: An event on 5 August 1994, Atmos. Environ., 30, 553-561, 1996.

Eichler, A., Tinner, W., Brütsch, S., Olivier, S., Papina, T., and Schwikowski, M.: An ice-core based history of Siberian forest fires since AD 1250, Quaternary Sci. Rev., 30, 1027-1034, 2011.

Finsinger, W. and Tinner, W.: Minimum count sums for charcoal concentration estimates in pollen slides: accuracy and potential errors, Holocene, 15, 293-297, 2005.

Fischer, H., Schüpbach, S., Gfeller, G., Bigler, M., Rothlisberger, R., Erhardt, T., Stocker, T. F., Mulvaney, R., and Wolff, E.: Millennial changes in North American wildfire and soil activity over the last glacial cycle, Nat. Geosci., 8, 723-728, 2015.

Flannigan, M., Cantin, A. S., de Groot, W. J., Wotton, M., Nwebery, A., and Gowman, L. M.: Global wildland fire season severity in the 21st century, Forest Ecol. Manag., 294, 54-61, 2013.

Giglio, L. and Justice, C.: MOD14A1 MODIS/Terra Thermal Anomalies/Fire Daily L3 Global $1 \mathrm{~km}$ SIN Grid V006 [Data set], NASA EOSDIS LP DAAC, https://doi.org/10.5067/MODIS/MOD14A1.006, 2015a.

Giglio, L., Justice, C., Boschetti, L., and Roy, D.: MCD64A1 MODIS/Terra+Aqua Burned Area Monthly L3 Global $500 \mathrm{~m}$
SIN Grid V006 [Data set], NASA EOSDIS Land Processes DAAC, https://doi.org/10.5067/MODIS/MCD64A1.006, 2015b.

Gilgen, A., Adolf, C., Brugger, S. O., Ickes, L., Schwikowski, M., van Leeuwen, J. F. N., Tinner, W., and Lohmann, U.: Implementing microscopic charcoal particles into a global aerosol-climate model, Atmos. Chem. Phys., 18, 11813-11829, https://doi.org/10.5194/acp-18-11813-2018, 2018.

Gogoi, M. M., Babu, S. S., Moorthy, K. K., Thakur, R. C., Chaubey, J. P., and Nair, V. S.: Aerosol black carbon over Svalbard regions of Arctic, Polar Sci., 10, 60-70, 2016.

Gogoi, M. M., Babu, S. S., Pandey, S. K., Nair, V. S., Vaishya, A., Girach, I. A., and Koushik, N.: Scavenging ratio of black carbon in the Arctic and the Antarctic, Polar Sci., 16, 10-22, 2018.

Gómez-González, S., Ojeda, F., and Fernandes, P. M.: Portugal and Chile: Longing for sustainable forestry while rising from the ashes, Environ. Sci. Policy, 81, 104-107, 2018.

Hantson, S., Pueyo, S., and Chuvieco, E.: Global fire size distribution is driven by human impact and climate, Global Ecol. Biogeogr., 24, 77-86, 2015.

Herren, P.-A., Eichler, A., Machguth, H., Papina, T., Tobler, L., Zapf, A., and Schwikowski, M.: The onset of Neoglaciation 6000 years ago in western Mongolia revealed by an ice core from the Tsambagarav mountain range, Quaternary Sci. Rev., 69, 59-69, 2013.

Hicks, S. and Isaksson, E.: Assessing source areas of pollutants from studies of fly ash, charcoal and pollen from Svalbard snow and ice, J. Geophys. Res., 111, D02113, https://doi.org/10.1029/2005JD006167, 2006.

Jacobson, J. Z.: Climate response of fossil fuel and biofuel soot, accounting for soot's feedback to snow and sea ice albedo and emissivity, J. Geophys. Res., 109, D21201, https://doi.org/10.1029/2004JD004945, 2004.

Kaspari, S., Skiles, S. M., Delaney, I., Dixon, D., and Painter, T. H.: Accelerated glacier melt on Snow Dome, Mount Olympus, Washington, USA, due to deposition of black carbon and mineral dust from wildfire, J. Geophys. Res.-Atmos., 120, 2793-2807, 2015.

Keegan, K. M., Albert, M. R., McConnell, J. R., and Baker, I.: Climate change and forest fires synergistically drive widespread melt events of the Greenland Ice Sheet, P. Natl. Acad. Sci. USA, 111, 7964-7967, 2014.

Keywood, M., Kanakidou, M., Stohl, A., Dentener, F., Grassi, G., Meyer, C. P., Torseth, K., Edwards, D., Thompson, A. M., Lohmann, U., and Burrows, J.: Fire in the air: Biomass burning impacts in a changing climate, Crit. Rev. Env. Sci. Tech., 43, 4083, 2013.

Konrad, H., Bohleber, P., Wagenbach, D., Vincent, C., and Eisen, O.: Determining the age distribution of Colle Gnifetti, Monte Rosa, Swiss Alps, by combining ice cores, ground-penetrating radar and a simple flow model, J. Glaciol., 59, 179-189, 2013.

Lamarque, J.-F., Bond, T. C., Eyring, V., Granier, C., Heil, A., Klimont, Z., Lee, D., Liousse, C., Mieville, A., Owen, B., Schultz, M. G., Shindell, D., Smith, S. J., Stehfest, E., Van Aardenne, J., Cooper, O. R., Kainuma, M., Mahowald, N., McConnell, J. R., Naik, V., Riahi, K., and van Vuuren, D. P.: Historical (1850-2000) gridded anthropogenic and biomass burning emissions of reactive gases and aerosols: methodology and application, Atmos. Chem. Phys., 10, 7017-7039, https://doi.org/10.5194/acp-10-7017-2010, 2010. 
Legrand, M. and DeAngelis, M.: Light carboxylic acids in Greenland ice: A record of past forest fires and vegetation emissions from the boreal zone, J. Geophys. Res.-Atmos., 101, 4129-4145, 1996.

Legrand, M., De Angelis, M., Staffelbach, T., Neftel, A., and Stauffer, B.: Large perturbations of ammonium and organic acids content in the Summit-Greenland ice core: Fingerprint from forest fires?, Geophys. Res. Lett., 19, 473-475, 1992.

Legrand, M., McConnell, J., Fischer, H., Wolff, E. W., Preunkert, S., Arienzo, M., Chellman, N., Leuenberger, D., Maselli, O., Place, P., Sigl, M., Schüpbach, S., and Flannigan, M.: Boreal fire records in Northern Hemisphere ice cores: a review, Clim. Past, 12, 2033-2059, https://doi.org/10.5194/cp-12-2033-2016, 2016.

Lim, S., Faïn, X., Ginot, P., Mikhalenko, V., Kutuzov, S., Paris, J.-D., Kozachek, A., and Laj, P.: Black carbon variability since preindustrial times in the eastern part of Europe reconstructed from Mt. Elbrus, Caucasus, ice cores, Atmos. Chem. Phys., 17, 3489-3505, https://doi.org/10.5194/acp-17-3489-2017, 2017.

Liu, D., Flynn, M., Gysel, M., Targino, A., Crawford, I., Bower, K., Choularton, T., Jurányi, Z., Steinbacher, M., Hüglin, C., Curtius, J., Kampus, M., Petzold, A., Weingartner, E., Baltensperger, U., and Coe, H.: Single particle characterization of black carbon aerosols at a tropospheric alpine site in Switzerland, Atmos. Chem. Phys., 10, 7389-7407, https://doi.org/10.5194/acp10-7389-2010, 2010.

Marlon, J. R., Kelly, R., Daniau, A.-L., Vannière, B., Power, M. J., Bartlein, P., Higuera, P., Blarquez, O., Brewer, S., Brücher, T., Feurdean, A., Romera, G. G., Iglesias, V., Maezumi, S. Y., Magi, B., Courtney Mustaphi, C. J., and Zhihai, T.: Reconstructions of biomass burning from sediment-charcoal records to improve data-model comparisons, Biogeosciences, 13, 3225-3244, https://doi.org/10.5194/bg-13-3225-2016, 2016.

MeteoSwiss: Bulletin Climatologique Juin 2017, Genève, 2017, available at: https://www.meteosuisse.admin.ch/home/ service-et-publications/publications.subpage.html/fr/data/ publications/2017/7/bulletin-climatologique-juin-2017.html? pageIndex $=5$ tab=search_tab, last access: 25 April 2019.

MeteoSwiss: Cendres des incendies portugais détectées en Suisse, available at: https://www.meteosuisse. admin.ch/home.subpage.html/fr/data/blogs/2017/6/

incendies-du-portugal-mesures-en-suisse (last access: 8 October 2018), 2017.

Moritz, M. A., Batllori, E., Bradstock, R. A., Malcolm Gill, A., Handmer, J., Hessburg, P. F., Leonard, J., McCaffrey, S., Odion, D. C., Schoennagel, T., and Syphard, A. D.: Learning to coexist with wildfire, Nature, 515, 58-66, 2014.

Motos, G., Schmale, J., Corbin, J. C., Modini, Rob. L., Karlen, N., Bertò, M., Baltensperger, U., and Gysel-Beer, M.: Cloud droplet activation properties and scavenged fraction of black carbon in liquid-phase clouds at the high-alpine research station Jungfraujoch (3580 m a.s.1.), Atmos. Chem. Phys., 19, 38333855, https://doi.org/10.5194/acp-19-3833-2019, 2019.

Mouillot, F. and Field, C.: Fire history and the global carbon budget: a $1^{\circ} \times 1^{\circ}$ fire history reconstruction for the 20th century, Global Change Biol., 11, 398-420, 2005.

Noone, K. J. and Clarke, A. D.: Soot scavenging measurements in Arctic snowfall, Atmos. Environ., 22, 2773-2778, 1988.

Osmont, D., Wendl, I. A., Schmidely, L., Sigl, M., Vega, C. P., Isaksson, E., and Schwikowski, M.: An 800-year high- resolution black carbon ice core record from Lomonosovfonna, Svalbard, Atmos. Chem. Phys., 18, 12777-12795, https://doi.org/10.5194/acp-18-12777-2018, 2018.

Osmont, D., Sigl, M., Eichler, A., Jenk, T. M., and Schwikowski, M.: A Holocene black carbon ice-core record of biomass burning in the Amazon Basin from Illimani, Bolivia, Clim. Past, 15, 579592, https://doi.org/10.5194/cp-15-579-2019, 2019.

Page, S. E., Siegert, F., Rieley, J. O., Boehm, H.-D. V., Jaya, A., and Limin, S.: The amount of carbon released from peat and forest fires in Indonesia during 1997, Nature, 420, 61-65, 2002.

Pechony, O. and Shindell, D. T.: Driving forces of global wildfires over the past millennium and the forthcoming century, P. Natl. Acad. Sci. USA, 107, 19167-19170, 2010.

Petzold, A. and Schönlinner, M.: Multi-angle absorption photometry - a new method for the measurement of aerosol light absorption and atmospheric black carbon, J. Aerosol Sci., 35, 421-441, 2004.

Petzold, A., Ogren, J. A., Fiebig, M., Laj, P., Li, S.-M., Baltensperger, U., Holzer-Popp, T., Kinne, S., Pappalardo, G., Sugimoto, N., Wehrli, C., Wiedensohler, A., and Zhang, X.-Y.: Recommendations for reporting "black carbon" measurements, Atmos. Chem. Phys., 13, 8365-8379, https://doi.org/10.5194/acp13-8365-2013, 2013.

Randerson, J. T., Liu, H., Flanner, M. G., Chambers, S. D., Jin, Y., Hess, P. G., Pfister, G., Mack, M. C., Treseder, K. K., Welp, L. R., Chapin, F. S., Harden, J. W., Goulden, M. L., Lyons, E., Neff, J. C., Schuur, E. A. G., and Zender, C. S.: The impact of boreal forest fire on climate warming, Science, 314, 1130-1132, 2006.

Reese, C. A., Liu, K. B., and Thompson, L. G.: An ice-core pollen record showing vegetation response to Late-glacial and Holocene climate changes at Nevado Sajama, Bolivia, Ann. Glaciol., 54, 183-190, 2013.

Rémy, S., Veira, A., Paugam, R., Sofiev, M., Kaiser, J. W., Marenco, F., Burton, S. P., Benedetti, A., Engelen, R. J., Ferrare, R., and Hair, J. W.: Two global data sets of daily fire emission injection heights since 2003, Atmos. Chem. Phys., 17, 2921-2942, https://doi.org/10.5194/acp-17-2921-2017, 2017.

Ruppel, M. M., Soares, J., Gallet, J.-C., Isaksson, E., Martma, T., Svensson, J., Kohler, J., Pedersen, C. A., Manninen, S., Korhola, A., and Ström, J.: Do contemporary (1980-2015) emissions determine the elemental carbon deposition trend at Holtedahlfonna glacier, Svalbard?, Atmos. Chem. Phys., 17, 12779-12795, https://doi.org/10.5194/acp-17-12779-2017, 2017.

Savarino, J. and Legrand, M.: High northern latitude forest fires and vegetation emissions over the last millennium inferred from the chemistry of a central Greenland ice core, J. Geophys. Res.Atmos., 103, 8267-8279, 1998.

Schroeder, W., Oliva, P., Giglio, L., and Csiszar, I. A.: The New VIIRS $375 \mathrm{~m}$ active fire detection data product: algorithm description and initial assessment, Remote Sens. Environ., 143, 85-96, https://doi.org/10.1016/j.rse.2013.12.008, 2014.

Schwarz, J. P., Gao, R. S., Fahey, D. W., Thomson, D. S., Watts, L. A., Wilson, J. C., Reeves, J. M., Darbeheshti, M., Baumgardner, D. G., Kok, G. L., Chung, S. H., Schulz, M., Hendricks, J., Lauer, A., Karcher, B., Slowik, J. G., Rosenlof, K. H., Thompson, T. L., Langford, A. O., Loewenstein, M., and Aikin, K. C.: Single-particle measurements of midlatitude black carbon and light-scattering aerosols from the boundary 
layer to the lower stratosphere, J. Geophys. Res., 111, D16207, https://doi.org/10.1029/2006JD007076, 2006.

Schwarz, J. P., Gao, R. S., Spackman, J. R., Watts, L. A., Thomson, D. S., Fahey, D. W., Ryerson, T. B., Peischl, J., Holloway, J. S., Trainer, M., Frost, G. J., Baynard, T., Lack, D. A., de Gouw, J. A., Warneke, C., and Del Negro, L. A.: Measurement of the mixing state, mass, and optical size of individual black carbon particles in urban and biomass burning emissions, Geophys. Res. Lett., 35, L13810, https://doi.org/10.1029/2008GL033968, 2008.

Schwikowski, M., Seibert, P., Baltensperger, U., and Gäggeler, H. W.: A study of an outstanding Saharan dust event at the high-alpine site Jungfraujoch, Switzerland, Atmos. Environ., 29, 1829-1842, 1995.

Sigl, M., Abram, N. J., Gabrieli, J., Jenk, T. M., Osmont, D., and Schwikowski, M.: 19th century glacier retreat in the Alps preceded the emergence of industrial black carbon deposition on high-alpine glaciers, The Cryosphere, 12, 3311-3331, https://doi.org/10.5194/tc-12-3311-2018, 2018.

Sinha, P. R., Kondo, Y., Goto-Azuma, K., Tsukagawa, Y., Fukuda, K., Koike, M., Ohata, S., Moteki, N., Mori, T., Oshima, N., Førland, E. J., Irwin, M., Gallet, J.-C., and Pedersen, C. A.: Seasonal Progression of the Deposition of Black Carbon by Snowfall at Ny-Ålesund, Spitsbergen, J. Geophys. Res.-Atmos., 123, 9971016, 2018.

Sprenger, M. and Wernli, H.: The LAGRANTO Lagrangian analysis tool - version 2.0, Geosci. Model Dev., 8, 2569-2586, https://doi.org/10.5194/gmd-8-2569-2015, 2015.

Stephens, M., Turner, N., and Sandberg, J.: Particle identification by laser-induced incandescence in a solid-state laser cavity, Appl. Optics, 42, 3726-3736, 2003.

Stier, P., Feichter, J., Kinne, S., Kloster, S., Vignati, E., Wilson, J., Ganzeveld, L., Tegen, I., Werner, M., Balkanski, Y., Schulz, M., Boucher, O., Minikin, A., and Petzold, A.: The aerosol-climate model ECHAM5-HAM, Atmos. Chem. Phys., 5, 1125-1156, https://doi.org/10.5194/acp-5-1125-2005, 2005.

Thomas, J. L., Polashenski, C. M., Soja, A. J., Marelle, L., Casey, K. A., Choi, H. D., Raut, J.-C., Wiedinmyer, C., Emmons, L. K., Fast, J. D., Pelon, J., Law, K. S., Flanner, M. G., and Dibb, J. E.: Quantifying black carbon deposition over the Greenland ice sheet from forest fires in Canada, Geophys. Res. Lett., 44, 79657974, 2017.

Tinner, W. and $\mathrm{Hu}, \mathrm{F}$. S.: Size parameters, size-class distribution and area-number relationship of microscopic charcoal: relevance for fire reconstruction, Holocene, 13, 499-505, 2003.

Uglietti, C., Zapf, A., Jenk, T. M., Sigl, M., Szidat, S., Salazar, G., and Schwikowski, M.: Radiocarbon dating of glacier ice: overview, optimisation, validation and potential, The Cryosphere, 10, 3091-3105, https://doi.org/10.5194/tc-10-30912016, 2016.
Wang, Z. W., Gallet, J. C., Pedersen, C. A., Zhang, X. S., Ström, J., and Ci, Z. J.: Elemental carbon in snow at Changbai Mountain, northeastern China: concentrations, scavenging ratios, and dry deposition velocities, Atmos. Chem. Phys., 14, 629-640, https://doi.org/10.5194/acp-14-629-2014, 2014.

Warren, S. G. and Clarke, A. D.: Soot in the atmosphere and snow surface of Antarctica, J. Geophys. Res., 95, 1811-1816, 1990.

Weber, H. and Wunderle, S.: Drifting Effects of NOAA Satellites on Long-Term Active Fire Records of Europe, Remote Sens., 11, 467, 2019.

Wendl, I. A., Menking, J. A., Färber, R., Gysel, M., Kaspari, S. D., Laborde, M. J. G., and Schwikowski, M.: Optimized method for black carbon analysis in ice and snow using the Single Particle Soot Photometer, Atmos. Meas. Tech., 7, 2667-2681, https://doi.org/10.5194/amt-7-2667-2014, 2014.

Wiedinmyer, C., Akagi, S. K., Yokelson, R. J., Emmons, L. K., AlSaadi, J. A., Orlando, J. J., and Soja, A. J.: The Fire INventory from NCAR (FINN): a high resolution global model to estimate the emissions from open burning, Geosci. Model Dev., 4, 625641, https://doi.org/10.5194/gmd-4-625-2011, 2011.

Whitlow, S., Mayewski, P., Dibb, J., Holdsworth, G., and Twickler, M.: An ice-core-based record of biomass burning in the Arctic and sub-Arctic, 1750-1980, Tellus B, 46, 234-242, 1994.

Yalcin, K., Wake, C. R., Kreutz, K. J., and Whitlow, S. I.: A 1000$\mathrm{yr}$ record of forest fire activity from Eclipse Icefield, Yukon, Canada, Holocene, 16, 200-209, 2006.

Zennaro, P., Kehrwald, N., McConnell, J. R., Schüpbach, S., Maselli, O. J., Marlon, J., Vallelonga, P., Leuenberger, D., Zangrando, R., Spolaor, A., Borrotti, M., Barbaro, E., Gambaro, A., and Barbante, C.: Fire in ice: two millennia of boreal forest fire history from the Greenland NEEM ice core, Clim. Past, 10, 1905-1924, https://doi.org/10.5194/cp-10-1905-2014, 2014.

Zhang, K., O’Donnell, D., Kazil, J., Stier, P., Kinne, S., Lohmann, U., Ferrachat, S., Croft, B., Quaas, J., Wan, H., Rast, S., and Feichter, J.: The global aerosol-climate model ECHAM-HAM, version 2: sensitivity to improvements in process representations, Atmos. Chem. Phys., 12, 8911-8949, https://doi.org/10.5194/acp-12-8911-2012, 2012.

Zhou, J., Tie, X., Xu, B., Zhao, S., Wang, M., Li, G., Zhang, T., Zhao, Z., Liu, S., Yang, S., Chang, L., and Cao, J.: Black carbon $(B C)$ in a northern Tibetan mountain: effect of Kuwait fires on glaciers, Atmos. Chem. Phys., 18, 13673-13685, https://doi.org/10.5194/acp-18-13673-2018, 2018. 